\title{
A Novel Dihydroxy Nor-Guaiane Sesquiterpene: Synthesis and Crystal Structure Analysis
}

\author{
Julio Zukerman-Schpector ${ }^{a, b^{*}}$, Ignez Caracelli ${ }^{b}$, Cristina C. Carvalho ${ }^{a}$, Mary ${ }_{b}$. de Faria ${ }^{b}$, \\ Fernando C. Silva ${ }^{b}$, Luiz G. de O. Matias ${ }^{b}$ and Timothy J. Brocksom ${ }^{b_{*}}$ \\ ${ }^{a}$ Departamento de Química Fundamental, Instituto de Química, Universidade de São Paulo, \\ C. P. 26077, 05513-970, São Paulo - SP, Brazil \\ ${ }^{\mathrm{b}}$ Departamento de Química, Universidade Federal de São Carlos, C. P. 676, 13565-905, São Carlos - SP, Brazil
}

\begin{abstract}
A epoxidação $\left(\mathrm{H}_{2} \mathrm{O}_{2}, \mathrm{NaOH}\right)$ de uma cicloeptenona-acetonilada forneceu um sesquiterpeno norguaiano bis-hidroxilado, através de uma sequiência inesperada de reações. Análise espectroscópica deste produto permitiu propor uma estrutura incluindo os grupos substituintes, porém a determinação tridimensional completa foi realizada por uma análise de difração de raio-X.
\end{abstract}

The epoxidation $\left(\mathrm{H}_{2} \mathrm{O}_{2}, \mathrm{NaOH}\right)$ of an acetonyl-cycloheptenone derived from (R)-(-)-carvone gives a dihydroxy-nor-guaiane sesquiterpene by way of an interesting sequence of reactions promoted by the basic reaction conditions. Although the major product could be identified spectroscopically with respect to functional groups, its complete three dimensional structure was determined by X-ray mono-crystal diffraction studies.

Keywords: nor-guaiane sesquiterpene, epoxidation, intramolecular aldol, $\beta, \gamma$-epoxy-ketone rearrangement, X-ray analysis

\section{Introduction}

Sesquiterpenes of the guaiane class $\mathbf{1}$ are encountered in plants of the Compositae family and less frequently in the Umbelliferae, Magnoliceae and Lauraceae ${ }^{1}$. Minor representatives of this class include the nor-guaianes 2 in which the $\mathrm{C}-15$ methyl group is lost probably due to oxidative metabolism of the parent guaiane.

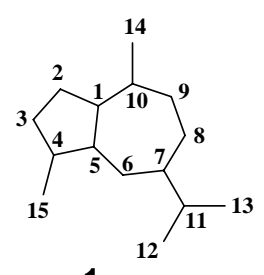

1

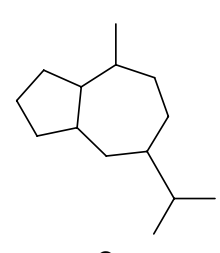

2

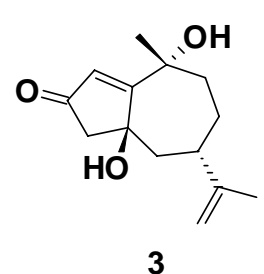

3
Both these groups of natural products present various biologically important activities such as anti-tumoral, antiulcerogenic, cytotoxic and insecticide properties ${ }^{1,2}$. This diversity of biological activity together with their structural complexity makes these compounds very interesting targets for synthetic organic chemists.

e-mail:julio@power.ufscar.br (J. Z-S., crystallography) and brocksom@zaz.com.br (T.J.B., chemistry)
In this paper we describe a novel dihydroxy nor-guaiane sesquiterpene $\mathbf{3}$, and its structure determination by spectroscopic and single crystal X-ray diffraction methods.

\section{Experimental}

2-Acetonyl-6-isopropenyl-3-methyl-cycloheptenone (6)

a) Allylation of cycloheptenone (5)

A solution of potassium tert-butoxide in tert-butanol was prepared from $1.231 \mathrm{~g}(31.48 \mathrm{mmol})$ of potassium and 62 $\mathrm{mL}$ of dry tert-butanol, under nitrogen, by heating at $70^{\circ} \mathrm{C}$ until complete reaction of the potassium. After cooling to room temperature, $4.00 \mathrm{~g}(24.39 \mathrm{mmol})$ of 6-isopropenyl-3-methyl-2-cycloheptenone 5 (or its $\beta, \gamma$ isomer; see reference 4) in $5 \mathrm{~mL}$ of dry tert-butanol was added and stirred for $20 \mathrm{~min}$, with formation of a wine colored solution. $2.2 \mathrm{~mL}$ ( $26.7 \mathrm{mmol})$ of allyl chloride was added slowly at $5^{\circ} \mathrm{C}$ and stirred for $1.5 \mathrm{~h}$, followed by dilution with water and extraction with dichloromethane and ethyl ether. After drying the organic extracts with anhydrous magnesium sulfate, concentration and column chromatography on silica gel, $2.985 \mathrm{~g}(60 \%)$ of the monoallylated cycloheptenone product was obtained, and used directly in the Wacker oxidation. ${ }^{1} \mathrm{H}$ NMR $(200 \mathrm{MHz}$, $\left.\mathrm{CDCl}_{3}\right) \delta 1.71$ (broad s, 3H), $1.90(\mathrm{~s}, 3 \mathrm{H}), 2.28-2.72(\mathrm{~m}$, 
$7 \mathrm{H}), 3.02-3.04(\mathrm{~d}, 2 \mathrm{H}, J 6 \mathrm{~Hz}), 4.72($ broad s, $2 \mathrm{H}), 4.86-$ $4.96(\mathrm{~m}, 2 \mathrm{H}), 5.65-5.81(\mathrm{~m}, 1 \mathrm{H}) ;{ }^{13} \mathrm{C}$ NMR $(50 \mathrm{MHz}$, $\left.\mathrm{CDCl}_{3}\right) \delta 204.1,152.5,147.8,135.8,114.3,109.8,46.6$, $40.1,33.8,32.8,30.0,23.1,21.0 ; \mathrm{IR} v_{\max } / \mathrm{cm}^{-1} 3060,2920$, 1650, 1430, 1360, 880 (neat).

\section{b) Wacker oxidation}

To a two-necked round bottom flask, coupled to a small balloon inflated with dry oxygen, was added $0.018 \mathrm{~g}$ $(0.10 \mathrm{mmol})$ of palladium chloride, $0.503 \mathrm{~g}(5.08 \mathrm{mmol})$ of cuprous chloride and $5.5 \mathrm{~mL}$ of aqueous dimethyl formamide (7:1 DMF:water) and stirred at room temperature for two $h$. The previously prepared allylcycloheptenone $(0.250 \mathrm{~g}, 1.22 \mathrm{mmol})$ was added and stirred for seventeen hours. A cold $1.5 \mathrm{~mol} \mathrm{~L}^{-1} \mathrm{HCl}$ solution was added and the mixture extracted five times with hexane. The organic phase was washed with $5 \%$ aqueous $\mathrm{NaHCO}_{3}$, saturated $\mathrm{NaCl}$, and dried over anhydrous $\mathrm{MgSO}_{4}$. Concentration and preparative thick plate chromatography furnished $0.274 \mathrm{~g}(66 \%)$ of the diketone 6. ${ }^{1} \mathrm{H}$ NMR $\left(80 \mathrm{MHz}, \mathrm{CDCl}_{3}\right) \delta 1.70(\mathrm{~s}, 3 \mathrm{H}), 1.80(\mathrm{~s}, 3 \mathrm{H}), 2.10(\mathrm{~s}$, $3 \mathrm{H}), 2.25-2.70(\mathrm{~m}, 7 \mathrm{H}), 3.40$ (s, $2 \mathrm{H}), 4.70$ (broad s, $2 \mathrm{H})$; ${ }^{13} \mathrm{C}$ NMR $\left(20 \mathrm{MHz}, \mathrm{CDCl}_{3}\right) \delta 205.7,203.4,153.9,147.6$, 132.3, 109.8, 46.2, 43.8, 39.9, 33.8, 29.9, 29.2, 23.5, 20.8; IR $v_{\max } / \mathrm{cm}^{-1} 3060,2920,1720,1650,1430,1350,880$ (neat).

\section{Di-hydroxy-nor-guaiane (3)}

To a cooled solution $\left(0{ }^{\circ} \mathrm{C}\right)$ of $95 \mathrm{mg}(0.43 \mathrm{mmol})$ of diketone 6 in $9.0 \mathrm{~mL}$ of methanol and $0.18 \mathrm{~mL}$ of $\mathrm{H}_{2} \mathrm{O}_{2}$ $30 \%, 0.05 \mathrm{~mL}$ of $\mathrm{NaOH} 6 \mathrm{~mol} \mathrm{~L}^{-1}$ was added, and stirred for $3 \mathrm{~h}$ at room temperature. The reaction mixture was then diluted with distilled water and extracted with ethyl acetate. After drying the organic layer with anhydrous $\mathrm{Na}_{2} \mathrm{SO}_{4}$ and evaporating the solvent, the resulting crude product (100 $\mathrm{mg}$ ) was purified by silica gel column chromatography using hexane and ethyl acetate (40:60) as eluent, and furnished 48 $\mathrm{mg}$ (47\% yield) of compound 3: $\mathrm{mp} 129.1-130.6{ }^{\circ} \mathrm{C} ;{ }^{1} \mathrm{H}$ $\operatorname{NMR}\left(400 \mathrm{MHz}, \mathrm{CDCl}_{3}\right) \delta 1.46-1.58(\mathrm{~m}, 2 \mathrm{H}), 1.50(\mathrm{~s}, 3 \mathrm{H})$, 1.69 (s, 3H), 1.69-1.77 (m, 1H), 1.93 (ddd, $1 \mathrm{H}, J$ 16.0, 8.0, $0.7 \mathrm{~Hz}), 2.04$ (broad s, 1H), 2.19 (broad s, 1H), 2.24 (ddd, $1 \mathrm{H}, J 16.0,4.0,2.1 \mathrm{~Hz}), 2.27$ (dd, $1 \mathrm{H}, J 16.0,12.0 \mathrm{~Hz}$ ), 2.45-2.52 (m, 1H), $2.60(\mathrm{~d}, 1 \mathrm{H}, J 20.0 \mathrm{~Hz}), 2.73(\mathrm{~d}, 1 \mathrm{H}, J$ $20.0 \mathrm{~Hz}), 4.69-4.71(\mathrm{~m}, 2 \mathrm{H}), 6.26(\mathrm{~s}, 1 \mathrm{H})$; the two broad singlets at $\delta 2.04$ and 2.19 disappeared on shaking with $\mathrm{D}_{2} \mathrm{O} ;{ }^{13} \mathrm{C}$ NMR $\left(100 \mathrm{MHz}, \mathrm{CDCl}_{3}\right) \delta 203.4,188.0,149.6$, 130.0, 109.8, 79.6, 74.9, 55.8, 49.0, 45.3, 40.6, 33.2, 28.7, 20.4; UV $\lambda_{\max } / \mathrm{nm}(\mathrm{MeOH}) 232.5$ ( 1 11.500); IR $v_{\max } /$ $\mathrm{cm}^{-1}$ 3427, 3381, 3070, 2975, 2930, 2860, 1694, 1447, 1194, 1051, 888 (neat); Anal. Calcd. for $\mathrm{C}_{14} \mathrm{H}_{22} \mathrm{O}_{4}$ : C, 71.16; H, 8.53. Found: C, 71.16; H, 8.60.

\section{$X$-ray structure determination of $\mathbf{3}$}

$\mathrm{X}$ ray data collection and refinement parameters are summarized in Table 1, the structure of the molecule with the atom-numbering is shown in Figure 1. Selected bond lengths and angles are given in Table 2. $\mathrm{H}$ atoms were placed in calculated positions, except those of the hydroxyl moieties, with fixed $\mathrm{C}-\mathrm{H}$ distances $\left(0.93 \AA\right.$ for $\mathrm{Csp}^{2}$ and $0.96 \AA$ for $\mathrm{Csp}^{3}$ ) each riding on a carrier atom, with an isotropic displacement parameter amounting to 1.5 (for methyl $\mathrm{H}$ atoms) or 1.2 (for the other $\mathrm{H}$ atoms) times the value of the equivalent isotropic displacement parameter of the atom they are attached. Programs used: cell determination and data collection: CAD4-Enraf-Nonius ${ }^{6}$; data reduction: Fair $^{7}$; structure determination: SHELXS- $86^{8}$; refinement: SHELXL-979 ; graphic presentation ZORTEP ${ }^{10}$; calculus of the Cremer and Pople's ${ }^{11}$ puckering parameters: CONFORMA ${ }^{12}$.

Table 1. Crystal data and structure refinement.

\begin{tabular}{|c|c|}
\hline Empirical formula & $\mathrm{C}_{14} \mathrm{H}_{22} \mathrm{O}_{4}$ \\
\hline Formula weight & 254.32 \\
\hline Temperature & 293(1) K \\
\hline Wavelength & $0.71073 \mathrm{~A}$ \\
\hline Crystal system & monoclinic \\
\hline Space group & $\mathrm{P} 2_{1} / \mathrm{a}$ \\
\hline \multirow[t]{4}{*}{ Unit cell dimensions } & $a=10.8224(7) \AA$ \\
\hline & $b=8.2680(10) \AA$ \\
\hline & $c=15.950(3) \AA$ \\
\hline & $\beta=102.780(10)^{\mathrm{o}}$ \\
\hline Volume & $1391.8(3) \AA^{3}$ \\
\hline $\mathrm{Z}$ & 4 \\
\hline Density (calculated) & $1.214 \mathrm{Mg} / \mathrm{m}^{3}$ \\
\hline Absorption coefficient & $0.088 \mathrm{~mm}^{-1}$ \\
\hline $\mathrm{F}(000)$ & 552 \\
\hline Crystal size & $0.25 \times 0.20 \times 0.20 \mathrm{~mm}$ \\
\hline$\theta$ range for data collection & 2.62 to $25.48^{\circ}$ \\
\hline Index ranges & $-13 \leq \mathrm{h} \leq 0,-10 \leq \mathrm{k} \leq 0,-18 \leq \mathrm{l} \leq 19$ \\
\hline Reflections collected & 2727 \\
\hline Independent reflections & $2577\left[\mathrm{R}_{\mathrm{int}}=0.0277\right]$ \\
\hline Refinement method & Full-matrix least-squares on $\mathrm{F}^{2}$ \\
\hline Data / restraints / parameters & $2577 / 0 / 167$ \\
\hline Goodness-of-fit on $\mathrm{F}^{2}$ & 1.010 \\
\hline Final $R$ indices $[\mathrm{I}>2 \sigma(\mathrm{I})]$ & $\mathrm{R} 1=0.0408, \mathrm{wR} 2=0.0940$ \\
\hline $\mathrm{R}$ indices (all data) & $\mathrm{R} 1=0.1166, w \mathrm{R} 2=0.1136$ \\
\hline Largest diff. peak and hole & 0.154 and -0.188 e. $\AA^{-3}$ \\
\hline
\end{tabular}

Table 2. Selected bond lengths $[\AA]$ and angles $\left[^{\mathrm{o}}\right]$.
$\mathrm{O}(1)-\mathrm{C}(10) 1.435(2)$
$\mathrm{O}(2)-\mathrm{C}(3) 1.228(2)$
$\mathrm{O}(3)-\mathrm{C}(5)$ 1.421(2)
$\mathrm{C}(1)-\mathrm{C}(2) 1.333(3)$
$\mathrm{C}(11)-\mathrm{C}(12) 1.341(3)$
$\mathrm{O}(2)-\mathrm{C}(3)-\mathrm{C}(2) 126.80(19)$
$\mathrm{O}(2)-\mathrm{C}(3)-\mathrm{C}(4) 125.5(2)$
C(2)-C(1)-C(5) 110.91(17)
$\mathrm{C}(1)-\mathrm{C}(2)-\mathrm{C}(3) 110.90(18)$
C(2)-C(3)-C(4) 107.64(17)
C(3)-C(4)-C(5) 104.24(16)
C(1)-C(5)-C(4) 102.09(16) 


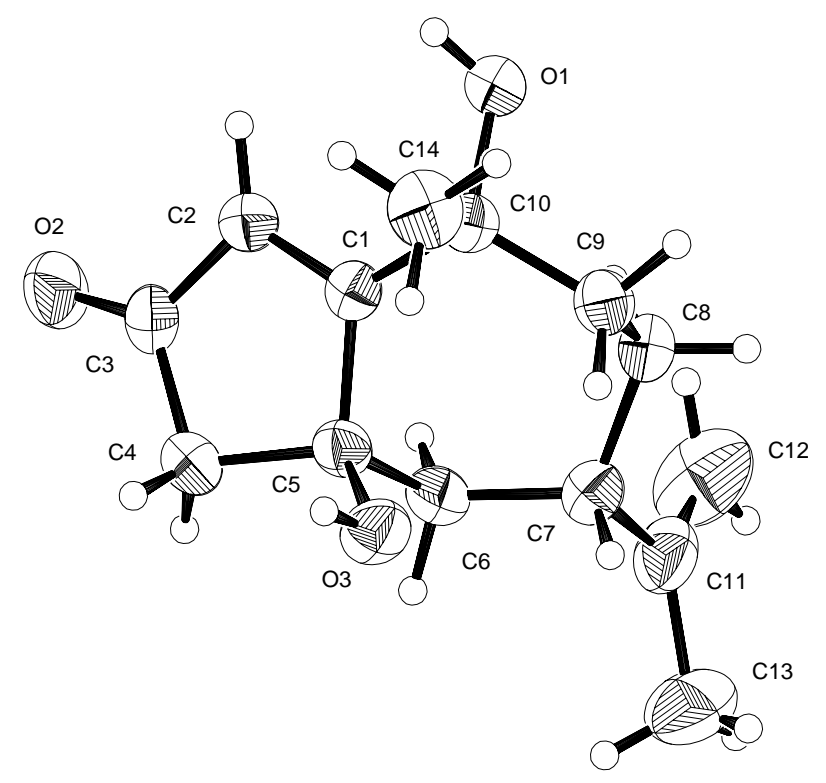

Figure 1. Projection of the molecular structure of $\mathbf{3}$ showing the atom labeling scheme. Displacement ellipsoids are drawn at the $50 \%$ probability level and $\mathrm{H}$ atoms are shown as spheres of arbitrary radii.

\section{Results}

R-(-)-carvone (4) was used as starting material, and transformed ${ }^{3,4}$ into the cycloheptenone 5 , which was monoallylated and Wacker oxidized to the 1,4-diketone 6. Our proposed next step was an intramolecular aldol reaction leading to the fused cyclopentenone ring of the norguaianes as in $\mathbf{7}$, but as previous experience had demonstrated $^{3}$ this reaction is inhibited ${ }^{5}$ by the $\mathrm{sp}^{2}$ hybridization of the ring carbon (C-2 of compound 6) linked to the side chain.

To avoid this problem we decided to epoxidize compound 6 using $\mathrm{H}_{2} \mathrm{O}_{2}(30 \%)$ and $\mathrm{NaOH} 6 \mathrm{~mol} \mathrm{~L}^{-1}$ in methanol, simultaneously transforming the $\mathrm{C}-2 \mathrm{sp}^{2}$ carbon of compound $\mathbf{6}$ into an $\mathrm{sp}^{3}$ carbon and temporarily protecting the endocyclic conjugated double bond as its epoxide. To our surprise the major reaction product $\mathbf{3}$, obtained in $47 \%$ yield, was found to be a hydroxylated cyclopentenone of the nor-guaiane type, as determined by conventional spectroscopic methods including infrared and ultraviolet absorption spectra, nuclear magnetic resonance spectra of both ${ }^{1} \mathrm{H}$ and ${ }^{13} \mathrm{C}$ nucleii, and microanalytical data.

Thus the saturated and $\alpha, \beta$-unsaturated carbonyl group absorptions of compound 6 in 1713 and $1653 \mathrm{~cm}^{-1}$ respectively, were replaced by an absorption in $1694 \mathrm{~cm}^{-1}$, and most surprising two distinct hydroxyl group absorptions in 3427 and $3381 \mathrm{~cm}^{-1}$ can be observed. The ${ }^{13} \mathrm{C}$ NMR spectrum shows two new $\mathrm{sp}^{2}$ carbon signals at $\delta$ 188.0 and 130.0, a unique carbonyl group carbon at $\delta 203.4$, and also two carbinolic carbons at $\delta 79.6$ and 74.9. The ${ }^{1} \mathrm{H}$ NMR spectrum shows a singlet at $\delta 6.26$ (one H), a singlet at $\delta 1.50$ (three $\mathrm{H}$ ) and two exchangeable singlets at $\delta 2.04$ and 2.19 (one $\mathrm{H}$ each).

Our interpretation of these spectral data lead to a structure proposal for compound $\mathbf{3}$, including a cyclopentenone norguaiane containing two independent hydroxyl groups. The first structure proposal was simply the 1-hydroxy- $\Delta-4$ isomer of the true structure (usual guaiane numbering as in 1). This structure could be proposed based upon the expected epoxidation, followed by an intramolecular aldol reaction with dehydration, and finally a simple hydrolytic opening of the resultant epoxide. However, as the spectroscopic data do not permit an unambiguous definition of structure even as to the two possible cyclopentenones, the position of the two hydroxyl groups, much less their relative configurations, a single crystal structure determination of $\mathbf{3}$ was undertaken.

\section{Discussion}

As can be seen in Figure 1 compound 3 is $(5 \mathrm{~S}, 7 \mathrm{~S}, 10 \mathrm{R})$ 5,10-dihydroxy-7-isopropenyl-10-methyl-bicyclo[5.3.0] dec-1-en-3-one.

The cyclopentenone ring adopts a distorted twist $\left({ }^{2} \mathrm{~T}_{1}\right)$ conformation, as shown by the Cremer \& Pople 11,12 parameters: $\mathrm{q}_{2}=0.203(2) \AA$ and $\varphi_{2}=61.0(6)^{\circ}$. The sevenmembered ring has a conformation that approximates closely to a chair conformation as shown by the fact that the smallest torsion angle in the ring is adjacent to the exocyclic C1-C2 double bond: C9-C10-C1-C5 = 29.3(6) ${ }^{\mathrm{O}}$. The Cremer \& Pople ${ }^{11}$ parameters are: $\mathrm{q}_{2}=0.456(2)$, $\mathrm{q}_{3}=0.650(2) \AA, \varphi_{2}=160.6(2), \varphi_{3}=109.8(2)^{\mathrm{o}}$.

The molecules are held together through hydrogen

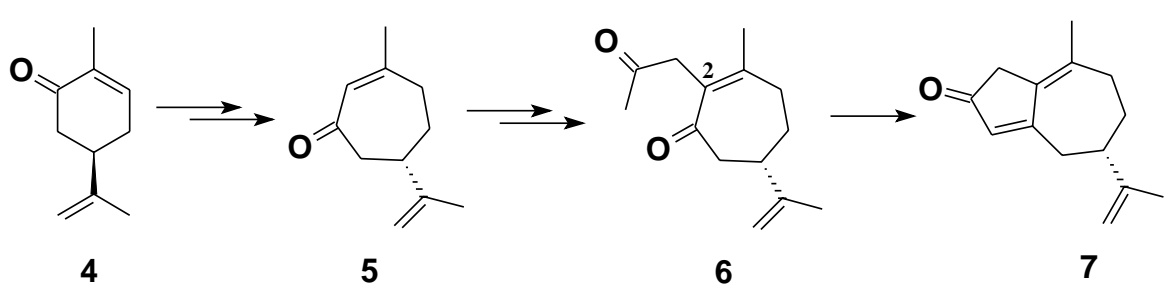

Scheme 1. 
bonds involving a crystallization water molecule as shown in Figure 2. The graph set method ${ }^{13}$, a language for describing and analysing these kind of hydrogen bonds nets, was used. In this method the topologies of the hydrogen bond patterns are considered rather than their particular geometries. The water molecule is involved in three hydrogen bonds, as a donor the primary graph set is DD and as acceptor is $\mathrm{D}(2)$. The di-hydroxy-norguaiane acts as a donor through the hydroxyl groups and as an acceptor through atom $\mathrm{O}(1)$ of the $\mathrm{C}(10)$ hydroxyl group and the carbonyl oxygen atom $\mathrm{O}(2)$; these hydrogen bonds are designated $\mathrm{D}(2)$, according to the primary graph set method. The hydrogen bonds parameters are shown in Table 3 and the second level graph set is shown in Table 4.

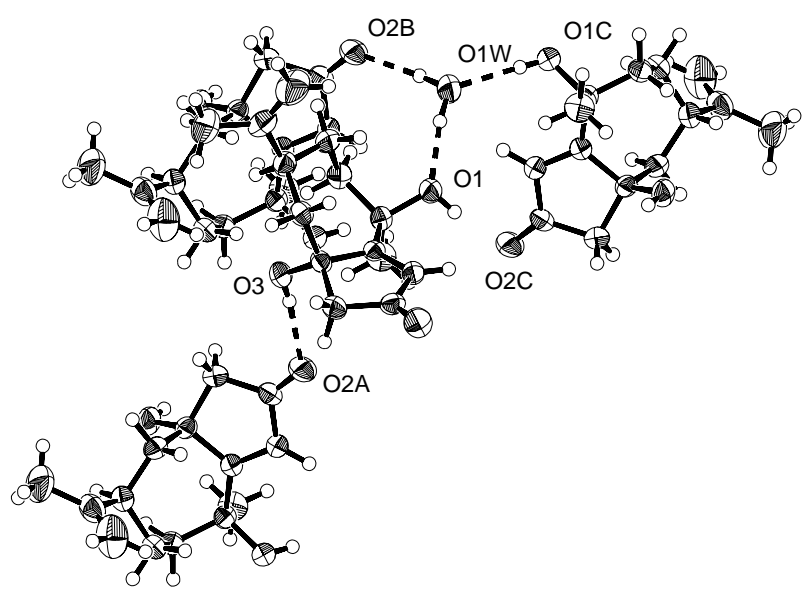

Figure 2. Hydrogen bond scheme.

Table 3. Hydrogen-bonding geometry $\left(\AA,^{\circ}\right)$

\begin{tabular}{|c|c|c|c|c|}
\hline & D-H...A & H...A & D...A & D-H...A \\
\hline $\mathrm{a}$ & $\mathrm{O}(1)-\mathrm{H} 1 \mathrm{O} 1 \ldots \mathrm{O} 1 \mathrm{~W}^{1}$ & 1.985 & $2.803(2)$ & 176 \\
\hline $\mathrm{b}$ & $\mathrm{O}(3)-\mathrm{H} 1 \mathrm{O} 3 \ldots \mathrm{O} 2^{\mathrm{ii}}$ & 1.994 & $2.810(2)$ & 173 \\
\hline $\mathrm{c}$ & $\mathrm{O}(1 \mathrm{~W})-\mathrm{H}(1 \mathrm{OW}) \ldots \mathrm{O}(1)$ & 1.895 & $2.858(2)$ & 169 \\
\hline d & $\mathrm{O}(1 \mathrm{~W})-\mathrm{H}(2 \mathrm{OW}) \ldots \mathrm{O}(2)^{\mathrm{iii}}$ & 1.930 & $2.858(2)$ & 175 \\
\hline
\end{tabular}

Symmetry codes: (i) $1.5-\mathrm{x}, 0.5+\mathrm{y}, 2-\mathrm{z}$; (ii) $-0.5+\mathrm{x}, 1.5-\mathrm{y}$, z; (iii) $\mathrm{x}-0.5,0.5-\mathrm{y}, \mathrm{z}$
Table 4. First and second-level hydrogen bond graph set motifs ${ }^{\mathrm{a}}$.

\begin{tabular}{cclll}
\hline & $\mathrm{a}$ & \multicolumn{1}{c}{$\mathrm{b}$} & \multicolumn{1}{c}{$\mathrm{c}$} & \multicolumn{1}{c}{$\mathrm{d}$} \\
\hline $\mathrm{a}$ & $\mathrm{D}(2)$ & $\mathrm{C}^{2}{ }_{2}(16)$ & $\mathrm{C}^{2}{ }_{2}(4)$ & $\mathrm{C}^{2}{ }_{2}(9)$ \\
$\mathrm{b}$ & & $\mathrm{D}(2)$ & $\mathrm{C}^{2}{ }_{2}(16)$ & $\mathrm{C}^{2}{ }_{2}(10)$ \\
$\mathrm{c}$ & & & $\mathrm{D}(2)$ & $\mathrm{D}^{2}{ }_{2}(5)$ \\
$\mathrm{d}$ & & & & $\mathrm{D}(2)$
\end{tabular}

aRows and columns headings correspond to the hydrogen bonds as defined in Table 3.

\section{Conclusion}

We can now propose an interesting sequence of reactions leading from diketone $\mathbf{6}$ to the product nor-guaiane $\mathbf{3}$ involving the expected epoxidation of the endocyclic conjugated double bond, taking place from the a face as defined by the configuration of the future C-10 hydroxyl group. Cyclization promoted by the base present in the reaction medium leads to an aldol intermediate with a $\beta$ hydroxyl group configuration. The basic medium promotes deprotonation and rearrangement of the $\beta, \gamma$ epoxy-ketone to the $\gamma$ hydroxy-cyclopentenone unit. The following scheme delineates a mechanistic route from diketone 6 to the major product 3. As far as we can determine this cascade sequence has not been reported previously.

\section{Acknowledgments}

The authors wish to thank FAPESP, CAPES and CNPq for financial support and student fellowships, and also Dragoco SA for gifts of (R)-(-)-carvone. The X-ray facility at IQ-USP was established with a grant from FAPESP (94/ 02061-4).

\section{Supplementary Material}

Crystallographic data (excluding structure factors) for the structures in this paper have been deposited with the Cambridge Crystallographic Data Centre as supplementary publication number CCDC 139603. Copies of the data can be obtained, free of charge, on application to CCDC, 12 Union Road, Cambridge CB2 1EZ, UK, (fax: +44-1223336033 or e-mail: deposit@ccdc.cam.ac.uk).
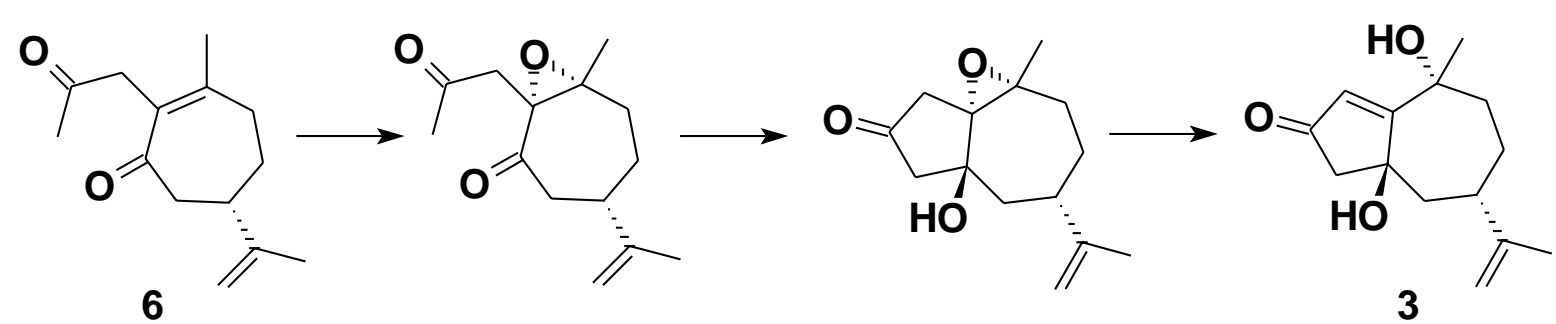

Scheme 2. 


\section{References}

1. Rodriguez, E.; Towers, G. H.; Mitchell, J. C. Phytochemistry, 1976, 15, 1573; Fraga, B. M. Nat. Prod. Rep., 1999, 16, 21; and earlier reviews cited therein.

2. Lee, E.; Lim, J. W.; Yoon, C. H.; Sung, Y.; Kim, Y. K. J. Am. Chem. Soc. 1997, 119, 8391; Picman, A. K. Biochem. Syst. and Ecol. 1986, 14, 255; Giordano, O. S.; Guerreiro, E.; Pestchanker, M. J. J. Nat. Prod. 1990, 53, 803.

3. Silva, F. C. M. Sc. Thesis, Departamento de Química, Universidade Federal de São Carlos, 1988; Matias. L. G. De O. M. Sc. Thesis, Departamento de Química, Universidade Federal de São Carlos, 1990; De Faria, M. L. Ph.D Thesis, Departamento de Química, Universidade Federal de São Carlos, 1998.

4. De Faria, M. L.; Magalhães, R. A.; Silva, F. C.; Matias, L. G. O.; Ceschi, M. A.; Brocksom, U.; Brocksom, T. J. Tetrahedron: Asymmetry 2000, 11, 4093.

5. The base catalyzed cyclization of 1,4-diketone 6 to the nor-guaiane 7 is a capricious reaction with variable yields (ref. 3), and the product 7 being an $\alpha, \beta, \gamma, \delta$ conjugated dienone does not offer the desired chemoselectivity on further chemical exploration. We justify the capricious nature of this aldol reaction as a consequence of the planarity of the endocyclic $\alpha, \beta$ enone system with the side chain acetonyl group, which does not easily permit the necessary superposition of the interacting enolate-carbonyl group orbitals.

6. Enraf-Nonius, CAD4-Software version 5.0. EnrafNonius, Delft, The Netherlands, 1989.

7. Fair, C.K. MolEN. An interactive Intelligent System for Crystal Structure Analysis. Enraf-Nonius, Delft, The Netherlands, 1990.

8. Sheldrick, G.M. SHELXS-86. Program for the Solution of Crystal Structures. University of Göttingen, Germany, 1986.

9. Sheldrick, G.M. SHELXL-97. Program for the Refinement of Crystal Structures. University of Göttingen, Germany, 1997.

10. Zsolnay, L. ZORTEP. An Interactive Molecular Graphics Program. Univ. of Heidelberg, Germany, 1995.

11. Cremer, D.; Pople, J. A. J. Am. Chem. Soc. 1975, 97, 1354.

12. Iulek, J.; Zukerman-Schpector, J. Quim. Nova. 1997, 20, 433.

13. Bernstein, J.; Davis, R.E.; Shimoni, L.; Chang, N. Angew. Chem. Int. Ed. Engl. 1995, 34, 1555.

Received: October 19, 1999

Published on the web: February 10, 2001

FAPESP helped in meeting the publication costs of this article. 